${ }^{1}$ Katedra i Klinika Chorób Wewnętrznych i Diabetologii, Uniwersytet Medyczny im. Karola Marcinkowskiego, Poznań

${ }^{2}$ Katedra i Klinika Nadciśnienia Tętniczego i Diabetologii, Uniwersytet Medyczny, Gdańsk

${ }^{3}$ Katedra Położnictwa i Chorób Kobiecych, Uniwersytet Medyczny im. Karola Marcinkowskiego, Poznań

${ }^{4}$ Katedra i Klinika Chorób Metabolicznych Collegium Medicum Uniwersytetu Jagiellońskiego, Kraków

${ }^{5}$ Klinika Endokrynologii, Diabetologii i Chorób Wewnętrznych, Uniwersytecki Szpital Kliniczny, Białystok

${ }^{6}$ Klinika Chorób Wewnętrznych, Diabetologii i Nefrologii, Śląski Uniwersytet Medyczny, Zabrze

${ }^{7}$ Klinika Choroby Wieńcowej, Instytut Kardiologii Collegium Medicum Uniwersytetu Jagiellońskiego; Szpital im. Jana Pawła II, Kraków

${ }^{8}$ Klinika Chorób Wewnętrznych, Endokrynologii i Diabetologii, Centralny Szpital Kliniczny MSWiA, Warszawa

${ }^{9}$ Klinika Diabetologii i Otyłości Wieku Rozwojowego, Uniwersytet Medyczny im. Karola Marcinkowskiego, Poznań

\title{
Compliance in diabetes - target or way to success?
}

\section{ABSTRACT}

In medicine, the term "compliance" is associated with medical practice and guidance, especially in relation to chronic diseases. Its definition has evolved with the development of modern medicine. In the last decade, the relationship between patient and doctor has changed significantly. The increasing importance of therapeutic success is attributed to the personalization of medicine and the consideration of patients' perspectives and preferences. The purpose of this manuscript is to find a modern definition of the term compliance in relation to diabetes and to determine what elements of personalized medicine can be incorporated into patient care to improve overall clinical success. In this article, the authors discuss the topics of compliance and personalized medicine in diabetes care taking into account both available medical publications as well as many years of the authors' own clinical experience. (Clin Diabet 2016; 5, 1: 32-39)

Key words: diabetes, compliance, patient, individualization

Address for correspondence:

prof. dr hab. n. med. Dorota Zozulińska-Ziółkiewicz

Katedra i Klinika Chorób Wewnętrznych i Diabetologii

Uniwersytet Medyczny im. Karola Marcinkowskiego, Poznań

e-mail: zozula@box43.pl

Clinical Diabetology 2016, 5, 1, 32-39

DOI: $10.5603 /$ DK.2016.0006

Translation: dr med. Jędrzej Toczko,

dr hab. med. Anna Korzon-Burakowska

Received: 20.10 .2015

Accepted: 03.12.2015

\section{Introduction}

A "Successful" treatment of diabetic patients seems to be clearly defined by clinical guidelines - as sustaining the desired glycemia, arterial pressure, lipid levels and body mass, thus preventing the occurrence of late complications and supporting patient's good quality of life. It is widely agreed that we have a number of effective antihiperglycemic, hypotensive or hypolipidemic drugs at our disposal. In the course of every patient's visit, we try to clearly communicate the desired way of treatment, encouraging him to follow it, gradually proceeding further with his education. However many of us would also admit that despite these scrupulous endeavours, our predefined goals are reached not quite as often as we would expect. Naturally, a question we ask ourselves is "why?" and, in many cases, a natural answer occurs, should we be frank about it: "because the patient doesn't follow my recommendations and does whatever he or she wants...". Nevertheless, assuming that every patient's greatest concern is his health and that he makes effort to proceed the best he can in given circumstances, it seems justified to try and take his viewpoint into account, creating a comprehensive perspective of the doctor-patient relationship, to which the term "compliance" is inseparably related.

Compliance is a term connected with therapeutic management and refers mainly to chronic diseases. However, its definition has evolved along with the development of modern medicine. A traditional viewpoint on compliance pictured it as the extent of following the therapeutic guidance by the patient - as a result, the doctor-patient relationship was usually reduced 
to presenting recommendations and overseeing their application [1]. In the last decade, both therapeutic guidelines concerning chronic diseases - including diabetes - and everyday clinical practice have seen a significant change of how the doctor-patient relationship is perceived. Increasing importance of therapeutic success is attributed to the personalization of medicine and consideration of patients' perspectives and preferences.

The purpose of this manuscript is to find a modern definition of the term compliance in relation to diabetes and to determine what elements of personalized medicine can be incorporated into patient's care to improve overall clinical success.

In this article, the authors discuss the topics of compliance and personalized medicine in diabetes care taking into account both available medical publications as well as many years of the authors' own clinical experience. We are fully aware that the descriptions included in certain parts of this article are to some extent generalisations and may not cover the depth of the topics mentioned completely, as each of them could be elaborated on separately. Nevertheless, we do hope that this article will contribute to the discussion among practicing physicians.

\section{Definition of compliance}

The English term compliance despite being a generally accepted and widespread medical definition, remains open to interpretation while being used in everyday speech. A quick dictionary search for a polish definition reveals many denotations, such as: subordination, conformance, submissiveness, pliancy or simply - cooperation. Many medical definitions
Table 1. Definition of compliance and related terms

Compliance - the quality of intentional, mutual cooperation between the doctor and the patient, resulting in accomplishment of therapeutic goals

Compliance includes the following elements:

Adherence - the extent to which the patient follows and fulfils the therapeutic guidance

Persistence - the long-lasting obedience and perseverance in fulfilling the guidance

also exist, ranging from straightforward - "two people cooperating to achieve various goals" [2] - to more complex descriptions, such as "any behaviour that brings the patient closer to achieving therapeutic goals" [3]. In addition, the term "compliance" is usually discussed inseparably with the terms "adherence" and "persistence", sharing many common semantic elements with them, despite not being directly included in their definition. These common parts, as regarded by the authors, are presented in the Table 1.

In addition, the authors point out five areas that may greatly affect attaining compliance in therapy of diabetes (Fig. 1), which are described in the latter parts of the manuscript.

\section{Communication}

Communication is one of the fundamental parts of an effective cooperation between the doctor and his patients. In its basic form, communication in a diabetic office is a mutual process of exchanging information between the patient and the doctor, the patient and the nurse or the doctor and the patient's family. Dur-

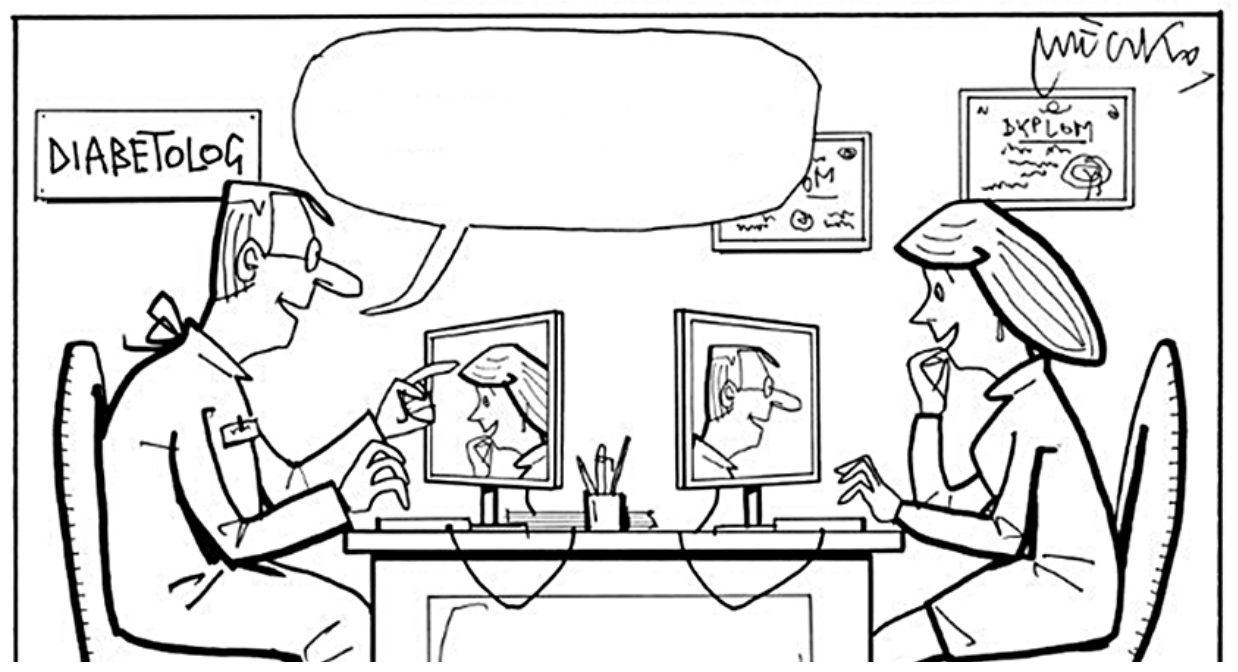

Figure 1. Five areas that greatly affect compliance 


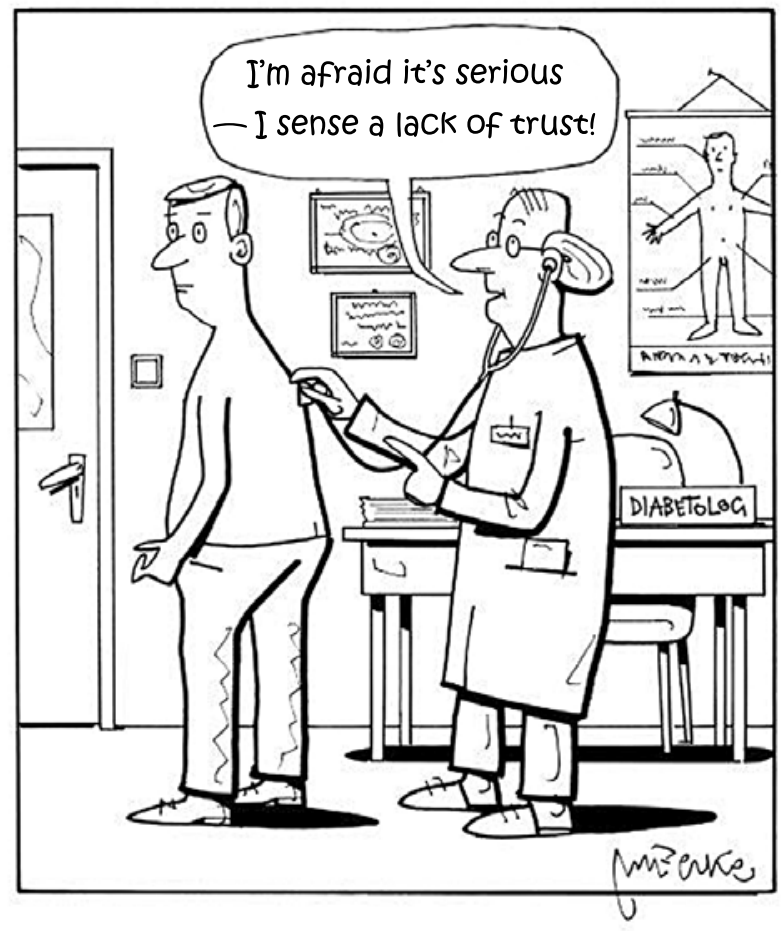

ing the consultation the doctor shares his knowledge with the patient, providing data concerning the chosen therapeutic option. On the other hand, the patient is the only source of information about his state of health, wellbeing and the ability of following the proposed therapy. Without effective communication it would be virtually impossible to educate the patient, involve him in the therapeutic process or sufficiently motivate him to seize control over his disease for a longer period of time [4]. Communication is the cornerstone of creating a trust-driven relationship between the doctor and the patient. Establishing such relationship may greatly contribute to following the doctor's guidance and, as a result, achieving the patient's therapeutic goals [5]. In authors' opinion, the key aspects of communication are:

\section{Adjusting the form and content}

of the message to the patient's knowledge,

abilities and comprehension

At its core, the main goal of communication is handing over the therapeutic guidance stemming from the doctor's knowledge and clinical experience. However these alone may be insufficient for this guidance to be understood, accepted and implemented. It is necessary to pass the information on in a comprehensible and plain manner, allowing it to be used and accepted by the patient. Emphasising the benefits of following the guidance and therefore controlling the disease, is a remarkably efficient way of communicating with the patient.

\section{Preparing a schedule of the visit}

One of the ways to reduce the impact of emotions on the efficiency of communication is preparing a schedule of the patient's visit. This allows preparing beforehand for a possible emotional response from our partner in dialogue, (e.g. in case of unfortunate news) and provides a resort in case of unexpected circumstances. One should also remember that verbal communication and a well adjusted message are only one part of the issue. Other elements, such as the vocal aspect, consisting of using proper voice pitch and timbre, or the visual aspect involving i.e. the appearance of the sender/receiver and their involvement in the conversation, facial expressions and gestures - may all contribute greatly to the process of communication [6].

\section{Striving for feedback and reassuring comprehension}

The communication between a diabetologist and his patient is a two-way process. Hearing the information that is channelled from the patient to his doctor is, besides reaching the patient with our own message, also essential to a successful therapy [7]. The doctor should react accordingly to the information given by the patient and answer his questions, being especially attentive when it comes to showing care and empathy, as well as keeping the message consistent with the ones handed out during prior visits. An effective method of assuring comprehension of the knowledge given is hearing the patient's feedback carefully, and kindly asking him to repeat the information in his own words [8].

\section{Using additional tools and communication channels}

Handing out additional materials during the visits, such as medical guidelines or diabetic diaries, is a good way of increasing the efficiency of communication. Using such tools simplifies and standardizes the communication process, making its effect last longer than just the duration of the visit. A diabetic diary (or a personal insulin pomp data log or a constant glucose measurement system) makes the patient's input more objective, to some extent. An interesting way of reaching beyond the time of the visit is using electronic and mobile communication, although it requires the aid of additional personnel and is currently unavailable to polish doctors due to legal and practical issues.

\section{Establishing proper conditions for communication}

An effective communication between the doctor and the patient may be affected by both intrinsic factors (e.g. personality or a specific emotional setting on the 
day of the visit) and external factors (e.g. noise outside or a mobile phone ringing) [9].

Communication between the doctor and the patient may have a great influence on achieving potential success of the therapy [10]. It is recommended for doctors to expand and develop their skills in that matter. Such process of self-improvement is a key also because of the new tools, solutions and therapeutic methods constantly emerging (e.g. insulin pumps with constant glucose measuring systems). These can bring real benefits to the patients, but also require the doctors to adjust their communication to fit modern reality.

\section{Education}

Educating a person with diabetes is one of the linchpins of modern diabetic care, crucial to moving the patient closer to set therapeutic goals, regardless of the therapy used [11]. The main purpose of education is to give knowledge, abilities and motivation to control diabetes. It helps achieving therapeutic goals agreed with the doctor, and increases effectiveness of the therapy [12]. While deliberating the influence of education on reaching therapeutic goals, one should consider following issues:

\section{Scheme and personalization}

Education's essential function is to provide a possibly unified set of basic terms and information for all persons involved, which then enables a dialogue during future appointments. However to be effective, education should also be personalized and tailored to the patient in order to involve him, promote self-reliance and motivate him to take partial responsibility for the treatment. One way of ensuring this is to encourage the patient to set, in cooperation with his physician, personal therapeutic goals related to the disease and then verify the progress of achieving them. It is not only a motivational boost for the patient, but also creates a good platform of exchanging information with the medical team, concerning the patient's state of health, his needs and attitude towards the therapeutic process.

\section{Using educational tools}

Another part of an effective education is to pass on proper information and tools which allow acting singlehandedly in everyday situations, both typical (e.g. regular glycaemia control, dietetic recommendations, suggested physical activity or avoiding hypoglycaemia) and those requiring special action (e.g. dealing with hypoglycaemia or omitting a medication dose) [13]. Due to limited time attributed to each patient during the visit, it seems promising to point out the educational tools available between the appointments. These

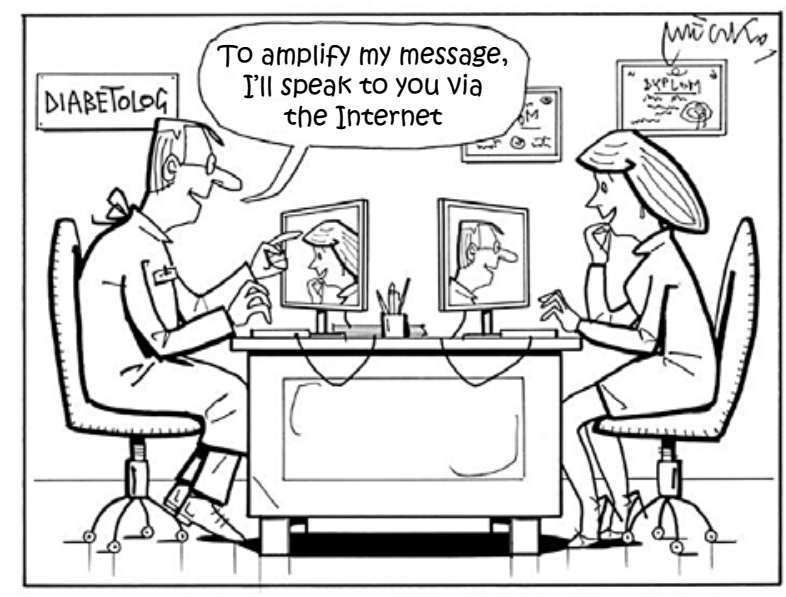

consist of traditional means such as brochures, books or patient associations' meetings on the one hand, and the rapidly expanding choice of electronic tools such as web portals devoted to certain issues, social media, blogs, webinars, online or handheld applications on the other. Incorporating various educational personnel (e.g. nurses, diabetes educators, psychologists, nutritionists, personal trainers) [14] into the process of education and aiming not only at the patient himself, but also at people in his close affinity (e.g. family members or other patients in the community), can greatly increase the chance of success [15].

\section{Repetitiveness}

Because of the extent of existing knowledge and the progressive nature of diabetes an efficient diabetic patient education is a constant process, not just a single event in the early stages of the disease [16]. In type 1 diabetes patients, the focus is set right from the start on using the intensive insulin therapy. In type 2 patients, along with progression of the disease comes the shifting in antihyperglycaemic therapy. Each change in the therapeutic scheme should indicate an introduction of a corresponding educational panel, covering certain topics ranging from oral medication, through basal insulin, to mixed insulin and intensive insulin therapy in a base-bolus scheme. Elements of education adjusted to the patient's needs and his therapeutic goals in the near future should be included in every visit.

\section{Adjusting form - individually and in groups}

Benefits of both individual education - provided by the therapeutic team or obtained individually via the internet or other means - and group education - traditional lectures, patient meetings, electronic message boards effectively reaching more patients, with effects lasting longer than a single-meeting education - are indisputable. According to some research, group educa- 
tion is not only equally effective in getting the required information through to the patient, but also more cost effective and results in a better glycaemia control [17].

\section{Up-to-date knowledge}

Efficient diabetic education should keep up with modern developments not only when its form is concerned, but also when it comes to the content it presents. The ever-growing choice of medicaments, medical technologies and other solutions - insulin pumps, constant glucose measurement systems, electronic diabetic and dietary diaries - ought to be presented in an accessible manner.

Passing on the knowledge about diabetes and skills necessary to cope with the disease and glycaemia control is a challenging task for the educational team, and present a great value for the patients. However, the fact of being educated itself doesn't necessarily grant the knowledge and practical abilities - these should be evaluated and, if necessary, complemented.

\section{Motivation}

One of the elements contributing to achieving therapeutic goals is sustaining a satisfactory level of patient's motivation - an inner state that induces action towards preservation or improvement of one's state of health [18]. Perceiving the disease as a threat and a punishment - or a nuisance and a challenge results in different attitudes towards the disease and the therapeutic process [19].

Therapeutic requirements in diabetes concerning changes in lifestyle diet, various habits or physical activity combined with seemingly non-aggravating symptoms - especially in a short term perspective and little awareness of the relation between the therapy and those symptoms, make motivating the patient to actively take part in the therapeutic process a difficult challenge. Analysis of factors affecting the patient's

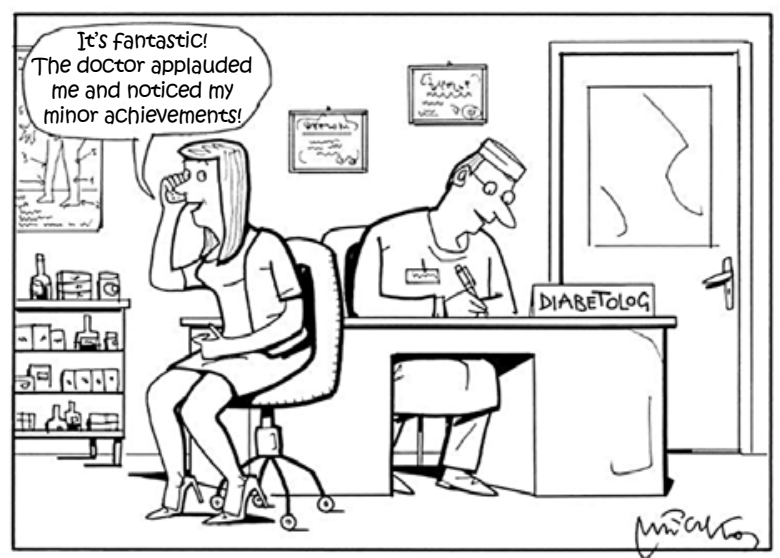

motivational processes in chronic disease unequivocally show their complex and multi-dimensional influence on patient's behaviour [20-23]. In authors' own opinion based on personal experience, the key factors in a therapeutic management of diabetic patients are:

\section{Setting the goal accordingly}

Personalization of therapeutic goals in a given stage of the disease, their acceptation and understanding by the patient. Creating an adequate timeline and enabling evaluation to mark progress, often by dividing the goals into stages. Confronting ambitions with reality.

\section{Making the goals important}

Finding a goal more valuable than others, one that can fulfil real needs of the patients, and therefore become a determinant of their actions in the long run.

\section{Positive motivation}

Regarded as sustaining an "aspiring for" attitude - which grows stronger as the patient gets closer to the promised reward. It should facilitate meeting the patients' needs, e.g. allowing better glycaemia control - the goal - which then lowers the risk of complications - blindness, amputation, the need for dialysis, granting longer life expectancy or a chance to give birth to a healthy infant - the reward. It is important to appreciate even minor achievements of the patient.

\section{A cause-effect relationship between} the patients' actions and his health

Giving a real sense of control of the disease, reinforcing awareness of the effects of actions both taken and omitted.

\section{Motivational atmosphere}

Resulting from the doctor-patient relationship and transferring the patient's approval for proposed therapy from the doctor's office (where the requirements seem easy to fulfil) to the patient's everyday life and surroundings.

When treating diabetes in children, inducing motivation in the child's parents is also crucial, as children tend to subconsciously mimic the parents' attitude. Pointing out the importance of determination in controlling the disease as the main way of assuring proper physical, intellectual and social development in their children's future - to a degree that had been expected before the disease occurred - is also an important way of promoting positive motivation. Motivational techniques concerning children vary depending on the patient's age and will be presented in a different article. A perfect example that pictures the potential of motiva- 
tion in therapy, are diabetic women who either plan pregnancy, or get pregnant at some point. The desire to give birth to healthy child results in better metabolic control in well educated patients during pregnancy when compared to other periods of their lives.

\section{Systemic measures}

Systemic measures are a difficult issue to elaborate on, as they rely on the organisation of medical care in different societies, leaving both doctors and patients little influence to be had. An organized effort could be expected from various groups and associations, formed by specialists, patients and doctors. The role of specialist organizations is creating standards of care on the basis of merit, whereas the patient groups should apply civic pressure on the decision-makers, to make sure these standards are in fact fulfilled.

\section{Therapy}

Therapeutic measures currently available in clinical practice enable a multidimensional influence on the pathophysiology of diabetes. Randomized controlled clinical trials and meta-analyzes determine the effects expected while using certain drug groups — or different groups combined - regarding their safety profile and efficiency. Clinical guidelines also clearly state reasonable models of initiating and intensifying therapies. The ability to choose between the given tools, ways and intensity of therapy is, from the doctor's point of view, a truly desired situation. There is no doubt that the doctor's choices may also influence the quality of doctor-patient cooperation in the therapeutic process.

\section{Personalization}

According to clinical guidelines, making a therapeutic choice should be a result of a broad analysis of many different clinical and personal features of the patient, e.g. his attitude and expected commitment



to therapy, diabetic education level, risk of hypoglycaemic events and their consequences, duration of diabetes, life expectancy, presence of serious vascular complications and significant concomitant diseases. The guidelines do not discriminate the importance of each criterion. The choice of therapy should be made based on a complex patient's profile, taking his expectations into account. From the patient's point of view, an optimal therapy is most likely a simple, easy to remember and easy to use scheme which is effective and causes no side effects. For each patient - or for the same patient in different stages of the disease - the significance of these elements changes, from "I want it to be effective" or "I am afraid of hypoglycaemia" to "I will surely gain weight". Taking the key patient's expectations and fears into account may contribute to a more effective cooperation in the long run (Fig. 2).

\section{Practical algorithms for unassisted patient decisions}

It is obvious that reaching therapeutic goals in diabetes requires the patient to actively take part in the

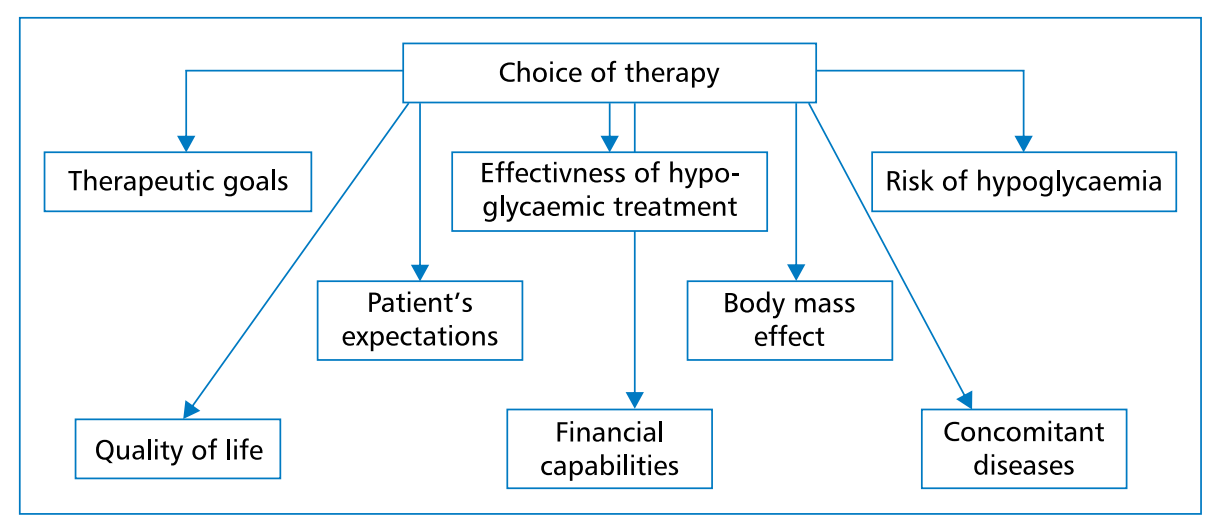

Figure 2. Factors determining personalized diabetes therapy, regarding therapeutic goals and the patient's point of view 
Table 2. Guidelines for a simplified, patient-managed dose adjustment of detemir insulin in adults with type 2 diabetes

\begin{tabular}{ll}
\hline Mean glycaemia & Detemir dose adjustment \\
\hline$>110 \mathrm{mg} / \mathrm{dl}(>6.1 \mathrm{mmol} / \mathrm{l})$ & +3 units \\
$80-110 \mathrm{mg} / \mathrm{dl}(4.4-6.1 \mathrm{mmol} / \mathrm{l})$ & No change (target glycaemia) \\
$<80 \mathrm{mg} / \mathrm{dl}(<4.4 \mathrm{mmol} / \mathrm{l})$ & -3 units \\
\hline
\end{tabular}

process at every stage of therapy. One of the solutions that strengthen the sense of having control over the disease is frequently using algorithms in clinical practice, which enable the patients to adjust the medication doses themselves, based on an honest glycaemia control. A 3-0-3 algorithm for patient-managed basal insulin - detemir - therapy intensification, reviewed in TITRATE [24] clinical trial, is an example of such solution. It enables adjusting the dosage of basal insulin in between the appointments by the patient himself. As a result the therapeutic goal defined as $\mathrm{HbA}_{1 \mathrm{c}}<7 \%$ with low risk of hypoglycaemia was achieved by $54.5 \%$ of patients with type 2 diabetes, who used insulin based therapy with detemir once a day. The option of patient-managed dose control was also indicated in the Summary of Product's Characteristic for detemir (Table 2) [25]. Patient-managed dose adjusting was also evaluated in a basal insulin therapy intensification model by adding additional postprandial injections of rapid-acting analogue [26]. In this project, the dose of mealtime insulin - aspart - was adjusted within one unit range - + $1,0,-1$ - based on the glycaemia levels before the meal, or before going to sleep.

\section{Flexibility of the therapeutic scheme}

The chronic nature of therapy of diabetes and its inseparable connection with everyday activity naturally makes the patient expect the recommended therapeutic scheme to be as flexible as possible. Therefore, such point of view shouldn't be overlooked while making therapeutic decisions. For example, the various recommended timings of prandial insulin injections (e.g. right before, during or after the meal for a rapid acting analogue compared to 20-30 minutes beforehand for human insulin) can greatly influence the way the patient perceives the therapy. Another interesting example of taking this aspect into consideration is the possibility of - if needed - injecting the degludec insulin, an ultra-long lasting base insulin, with a shift in time, determined in the Summary of Product's Characteristic as 8 to 40 hours after previous injection [27].

\section{Summary}

Taking the patient's point of view into consideration in everyday therapeutic decisions and personal- izing the therapeutic process based on his clinical and psychological profile undoubtedly set a clear direction for diabetes specialists and will remain relevant in the future. Compliance defined as the quality of purposeful and mutual cooperation seems to be fundamental in increasing the chance of making optimal choices and reaching the goals of proposed therapy. Raising the quality of this cooperation requires not only a personalized therapeutic approach and organized education in an innovative form, but also demands a systematic increase in doctors' expertise in effective communication and motivational techniques used in a therapeutic process.

\section{Conflict of interest}

The authors are members of Advisory Board of Novo Nordisk.

\section{Cartoons by Andrzej Mleczko}

\section{REFERENCES}

1. Crawford WC. Problems of compliance and enforcement under the drug law. Food Drug Cosmet Law Q 1947; 2: 445-454.

2. Funnell MM, Anderson RM. The problem with compliance in diabetes. JAMA 2000; 284: 1709.

3. Hussey LC, Gilliland K. Compliance, low literacy, and locus of control. Nurs Clin North Am 1989; 24: 605-611.

4. Elwyn G, Edwards A, Kinnersley P, Grol R. Shared decision making and the concept of equipoise: the competences of involving patients in healthcare choices. Br J Gen Pract 2000; 50: 892-899.

5. Ochsner J. Doctor-Patient Communication: A Review. Spring 2010; 10: 38-43.

6. Silverman S, Gold DT. Compliance and persistence with osteoporosis medications: A critical review of the literature. Rev Endocr Metab Disord 2010; 11: 275-280.

7. Korsch BM, Caroline H. Świadomy pacjent - Jak mówić, żeby lekarz Cię słuchał. Prószyński i S-ka, Warszawa 1999.

8. Bredart A, Bouleuc C, Dolbeault S. Doctor-patient communication and satisfaction with care in oncology. Curr Opin Oncol 2005 17: 351-354

9. Quill TE. Recognizing and Adjusting to Barriers in Doctor-Patient Communication. Ann Intern Med 1989; 111: 51-57.

10. Stewart MA. Effective physician-patient communication and health outcomes: a review. CMAJ 1995; 152: 1423-1433.

11. Brown SA. Diabetes patients education intervention and outcomes: a meta analysis revisited. Patient Educ Cons 1990; 16: 189-215.

12. Koev DJ, Tankova TI, Kozlovski PG et al. Effect of structured group education on glycemic control and hypoglycemia in insulin-treated patients. Diabetes Care 2003; 26: 251.

13. Loveman E, Frampton GK, Clegg AJ. The clinical effectiveness of diabetes education models for type 2 diabetes: a systematic review. Health Technol Assess 2008; 12: 1-116. 
14. Fisher DW, Culhane B, Clarke RL et al. Keeping pace: video communications in a managed care environment. Manag Care $\mathrm{Q}$ 1998; 6: 36-42.

15. Funnell MM, Brown TL, Childs BP et al. National standards for diabetes self-management education. Diabetes Care 2007; 30: 1630-1637.

16. Rickheim PL, Weaver TW, Flader JL et al. Assessment of group versus individual diabetes education: a randomized study. Diabetes Care 2002; 25: 269-274.

17. Christie D, Channon S. The potential for motivational interviewing to improve outcomes in the management of diabetes and obesity in paediatric and adult populations: a clinical review. Diabetes Obes Metab 2013. doi: 10.1111/dom.12195.

18. White RD. Patient empowerment and optimal glycemic control. Curr Med Res Opin 2012; 28: 979-989.

19. Serrano-Gil M, Jacob S. Engaging and empowering patients to manage their type 2 diabetes, Part I: a knowledge, attitude, and practice gap? Adv Ther 2010; 27: 321-333.

20. Miller CK, Bauman J. Goal setting: an integral component of effective diabetes care. Curr Diab Rep 2014; 14: 509.

21. Jones $A$, Gladstone $B P$, Lübeck $M$ et al. Motivational interventions in the management of $\mathrm{HbA} 1 \mathrm{c}$ levels: a systematic review and meta-analysis. Prim Care Diabetes 2014; 8: 91-100.
22. Ahola AJ, Groop PH. Barriers to self-management of diabetes. Diabet Med 2013; 30: 413-420.

23. Jacob S, Serrano-Gil M. Engaging and empowering patients to manage their type 2 diabetes, Part II: Initiatives for success. Adv Ther 2010; 27: 665-680.

24. Blonde $L$, Merilainen $M$, Karwe $V$ et al. Patient-directed titration for achieving glycaemic goals using a once-daily basal insulin analogue: an assessment of two different fasting plasma glucose targets — the TITRATE study. Diabetes Obes Metab 2009; 11: 623-631.

25. Detemir - Charakterystyka Produktu Leczniczego (http://www. ema.europa.eu/ema/index.jsp?curl=pages/medicines/human/ /medicines/000528/human_med_000884.jsp\&mid=WC0b01 ac058001d124).

26. Rodbard HW, Visco VE, Andersen $\mathrm{H}$ et al. Treatment intensification with stepwise addition of prandial insulin aspart boluses compared with full basal-bolus therapy (FullSTEP Study): a randomised, treat-to-target clinical trial. Lancet Diabetes Endocrinol 2014; 2: 30-37.

27. Degludec - Charakterystyka Produktu Leczniczego (http://www. ema.europa.eu/ema/index.jsp?curl=pages/medicines/human/ /medicines/002498/human_med_001609.jsp\&mid=WC0b01ac 058001d124). 
